\title{
Evaluation of Wheat Germplasm for Resistance to Leaf Rust (Puccinia triticina) and Identification of the Sources of $\mathrm{Lr}$ Resistance Genes Using Molecular Markers
}

\author{
Alma Kokhmetova ${ }^{1,2, *}$, Shynbolat Rsaliyev ${ }^{3, *}$, Makpal Atishova ${ }^{1}$, Madina Kumarbayeva ${ }^{1,2}\left({ }^{1}\right.$, \\ Angelina Malysheva $^{1}{ }^{\oplus}$, Zhenis Keishilov ${ }^{1} \oplus$, Danna Zhanuzak ${ }^{1}{ }^{1}$ and Ardak Bolatbekova ${ }^{1}$ \\ 1 Institute of Plant Biology and Biotechnology, Almaty 050040, Kazakhstan; maki_87@mail.ru (M.A.); \\ madina_kumar90@mail.ru (M.K.); malysheva_angelina@list.ru (A.M.); jeka-sayko@mail.ru (Z.K.); \\ dolphin_969@mail.ru (D.Z.); ardashka1984@mail.ru (A.B.) \\ 2 Faculty of Agrobiology, Kazakh National Agrarian Research University, Almaty 050010, Kazakhstan \\ 3 Kazakh Research Institute of Agriculture and Plant Growing, Almalybak 040909, Kazakhstan \\ * Correspondence: gen_kalma@mail.ru (A.K.); shynbolat63@mail.ru (S.R.); \\ Tel.: +87-273-947-552 (A.K.); +87-017-912-518 (S.R.); Fax: +87-273-94-75-62 (S.R.)
}

check for updates

Citation: Kokhmetova, A.; Rsaliyev, S.; Atishova, M.; Kumarbayeva, M.; Malysheva, A.; Keishilov, Z; Zhanuzak, D.; Bolatbekova, A. Evaluation of Wheat Germplasm for Resistance to Leaf Rust (Puccinia triticina) and Identification of the Sources of $L r$ Resistance Genes Using Molecular Markers. Plants 2021, 10, 1484. https://doi.org/10.3390/ plants10071484

Academic Editors: Tomislav Duvnjak and Aleksandra Sudarić

Received: 15 June 2021

Accepted: 14 July 2021

Published: 20 July 2021

Publisher's Note: MDPI stays neutral with regard to jurisdictional claims in published maps and institutional affiliations.

Copyright: (C) 2021 by the authors Licensee MDPI, Basel, Switzerland. This article is an open access article distributed under the terms and conditions of the Creative Commons Attribution (CC BY) license (https:/ / creativecommons.org/licenses/by/ $4.0 /)$.
Abstract: Leaf rust, caused by Puccinia triticina (Ptr), is a significant disease of spring wheat spread in Kazakhstan. The development of resistant cultivars importantly requires the effective use of leaf rust resistance genes. This study aims to: (i) determine variation in Ptr population using races from the East Kazakhstan, Akmola, and Almaty regions of Kazakhstan; (ii) examine resistance during seedling and adult plant stages; and (iii) identify the sources of $L r$ resistance genes among the spring wheat collection using molecular markers. Analysis of a mixed population of Ptr identified 25 distinct pathotypes. Analysis of these pathotypes using 16 Thatcher lines that are near-isogenic for leaf rust resistance genes $(L r)$ showed different virulence patterns, ranging from least virulent "CJF/B" and "JCL/G" to highly virulent "TKT/Q". Most of the pathotypes were avirulent to $\operatorname{Lr} 9, \operatorname{Lr} 19$, Lr24, and Lr25 and virulent to Lr1, Lr2a, Lr3ka, Lr11, and Lr30. The Ptr population in Kazakhstan is diverse, as indicated by the range of virulence observed in five different races analyzed in this study. The number of genotypes showed high levels of seedling resistance to each of the five Ptr races, thus confirming genotypic diversity. Two genotypes, Stepnaya 62 and Omskaya 37, were highly resistant to almost all five tested Ptr pathotypes. Stepnaya 62, Omskaya 37, Avangard, Kazakhstanskaya rannespelaya, and Kazakhstanskaya 25 were identified as the most stable genotypes for seedling resistance. However, most of the varieties from Kazakhstan were susceptible in the seedling stage. Molecular screening of these genotypes showed contrasting differences in the genes frequencies. Among the 30 entries, 22 carried leaf rust resistance gene $\operatorname{Lr} 1$, and two had $\operatorname{Lr} 9$ and $\operatorname{Lr} 68$. $\operatorname{Lr} 10$ and Lr28 were found in three and four cultivars, respectively. Lr19 was detected in Omskaya 37. Two single cultivars separately carried Lr26 and Lr34, while Lr37 was not detected in any genotypes within this study. Field evaluation demonstrated that the most frequent $L r 1$ gene is ineffective. Kazakhstanskaya 19 and Omskaya 37 had the highest number of resistance genes: three and four $L r$ genes, respectively. Two gene combinations (Lr1, Lr68) were detected in Erythrospermum 35 and Astana. The result obtained may assist breeders in incorporating effective $L r$ genes into new cultivars and developing cultivars resistant to leaf rust.

Keywords: wheat; leaf rust; $\operatorname{Lr}$ genes; virulence; pathotypes; molecular markers

\section{Introduction}

Central Asia, including Kazakhstan, is a significant player in regional and global food security, producing most of the grain traded in the region, with total area sown to wheat in Kazakhstan representing over $85 \%$ of total cereal production [1]. One of the main reasons for the reduction in the yield of wheat in Kazakhstan is the disease with airborne infection. 
Dominant position, as a part of the pathogenic complex of wheat in Kazakhstan, is taken by rusts (yellow, stem, and leaf rust) [2-5], as well as leaf spot diseases (tan spot and Septoria) [6-11].

Wheat leaf rust fungus, Puccinia triticina (Ptr), is found in major wheat-growing regions of the world and is a leading cause of yield loss in wheat. Populations of $P$. triticina are highly variable for virulence to resistance genes in wheat and adapt quickly to resistance genes in wheat cultivars [12]. It caused serious damage to both yield and quality. On average, the disease causes $21.5 \%$ of yield losses in wheat globally [13].

Wheat-growing regions of Kazakhstan have been facing frequent occurrences of leaf rust epidemics. Between 2001 and 2009, North Kazakhstan suffered leaf rust epidemics that occurred five times $(2002,2003,2005,2007$, and 2009), and the yield loss due to leaf rust has been reported to range from $10 \%$ to $50 \%$ in the most susceptible cultivars $[3,14]$. Leaf rust in Kazakhstan is spread from $4 \%$ to $61 \%$ of the surveyed area, which represents approximately from 0.5 to 3 million hectares. Review on leaf rust incidence, virulence, and breeding in northern Kazakhstan and Siberia [15] found that the pathogen affects up to 5 Mha of spring wheat on average one year out of four with yield losses of $25 \%$ to $30 \%$. The use of genetically rust-resistant cultivars is considered to be the most efficient, cost-effective, and environmentally safe method for disease control.

Seedling resistance (all-stage resistance) and adult plant resistance (APR) are the main categories used to describe the reaction of wheat to rust [16]. APR genes provide resistance to individual or all pathotypes of the fungus [17]. Race-nonspecific APR-resistance provides partial (or slow-rusting) resistance [18]. Currently, $79 \mathrm{Lr}$ genes for resistance to leaf rust have been identified [19]. Some APR genes are race-specific (Lr12) [20], others are race non-specific (Lr34, Lr46, Lr67, Lr68, Yr36, and Sr2) [21]. Race-specific APR genes Lr34 [22], Lr67 [23], and Yr36 [24] were cloned; it was found that they encode the ABC and hexose transporters and the kinase START gene, respectively. New mechanisms of resistance of these classes of genes lead to pleiotropism and long-term resistance. Several race-specific Lr genes belong to the NBS-LRR (nucleotide-binding site leucine-rich repeat) class and encode receptor proteins on the signal transduction pathway that appears in response to pathogen exposure [25].

Diversity in $\mathrm{Lr}$ genes in commercial cultivars could play an important role in managing frequent leaf rust epidemics in the region. Previous studies carried out in Kazakhstan showed that emergence of new virulent races of the pathogen leads to the ineffectiveness of a number of $\operatorname{Lr}$ genes. Genes $\operatorname{Lr} 9, \operatorname{Lr} 10, \operatorname{Lr} 19, \operatorname{Lr} 34, \operatorname{Lr} 37$, and $\operatorname{Lr} 68$ are still effective, while Lr1 has lost its effectiveness [26,27]. The comparative study of population structure in the West Asian region of Russia and northern Kazakhstan revealed high genetic similarity in virulence and phenotypic composition between Omsk and North Kazakhstan, Omsk and Chelyabinsk populations [28]. The study on leaf rust incidence, virulence, and breeding in northern Kazakhstan and Siberia showed the absence of virulence for genes Lr9 and Lr24 in the leaf rust population and a low proportion of isolates with virulence to Lr11, Lr16, Lr18, and Lr28. The field observations indicated that genes Lr28 and Lr36 provide resistance [15]. Avirulence to $L r 19$ and $L r 24$ and virulence to $L r 3 a, L r 3 b g, L r 3 k a, L r 14 a, L r 14 b$, Lr16, Lr17, and Lr30 was shown in a more detailed study of 2016 targeting these regions. The proportion of isolates virulent to $\operatorname{Lr} 1, \operatorname{Lr} 2 a, \operatorname{Lr} 2 b, \operatorname{Lr} 2 c, \operatorname{Lr} 9, \operatorname{Lr} 15, \operatorname{Lr} 18, \operatorname{Lr} 20$, and $\operatorname{Lr} 26$ varied depending on location [29].

Some of the $L r$ genes are closely linked to other resistance genes, e.g., $L r 19 / S r 25$; Lr26/Yr9/Sr31/Pm8, Lr37/Yr17/Sr38, and Lr34/Yr18/Pm38, that are still effective or represent great interest as donors of valuable agronomic traits in Kazakhstan [4].

The leaf rust population showed an absence of virulence for genes Lr9 and Lr24 and a low proportion of isolates with virulence to $\operatorname{Lr11}, \operatorname{Lr} 16, \operatorname{Lr} 18$, and $\operatorname{Lr} 28$. The field observations indicated that genes $\operatorname{Lr} 28$ and $L r 36$ provide resistance.

Previous studies have reported variations in Ptr populations in Kazakhstan [4,27,30]. It is therefore necessary to periodically evaluate resistant cultivars and advanced breeding 
lines against Ptr races in order to monitor resistance breakdown and plan the replacement of susceptible cultivars with resistant cultivars.

Identification and selection of resistant genes through gene postulation and other plant protection and breeding strategies are time-consuming and cannot be employed if no different fungal isolates are available [31,32]. The molecular marker technology-the most accurate and efficient tool to screen wheat material against various genes, conferring resistance to rust pathogens, and for developing disease-resistant cultivars-is needed to overcome these problems [31-34].

Understanding the nature of resistance and prevention of genetic erosion leading to a rapid efficiency loss of used genes requires screening of new material. The screening should include the identification of resistance genes using molecular markers, as well as the study of the response of seedlings and adult plants of commercial varieties and advanced breeding lines to the Ptr pathotypes.

There is an understanding of adult plant resistance to leaf rust in winter wheat $[4,27]$, but there is limited information available on $\mathrm{Lr}$ genes present in commercial cultivars and advanced breeding lines of spring wheat from Kazakhstan.

Several recent reports listed a number of released cultivars and advanced breeding lines of wheat in Kazakhstan and Russia that were resistant to leaf rust [27,30,35], but their reactions to the diverse Ptr races of Kazakhstan is not known. This study aims to: (i) determine variation in Ptr population using races from East Kazakhstan, Akmola, and Almaty regions of Kazakhstan; (ii) examine seedling and adult plant stage resistance; and (iii) identify the sources of resistance among the spring wheat collection using molecular markers.

\section{Results}

\subsection{Races of Puccinia triticina and Their Virulence Pattern}

Use of 16 Tc $L r$-lines helped to identify 25 virulence phenotypes of $P$. triticina from leaf rust-infected leaf samples that were collected in East Kazakhstan (East), Akmola (North), and Almaty (Southeast) regions of Kazakhstan during the 2019 and 2020 seasons (Table 1). The northern population of leaf rust is more numerous (12 pathotypes) and more virulent in comparison to the eastern (8 pathotypes) and the southeastern (4 pathotypes) population. The virulence patterns of the pathotypes ranged from least virulent "CJF/B" and "JCL/G" (virulent on 5 of 16 differentials) to highly virulent "TKT/Q" (virulent on 13 of the 16 differentials). The isogenic lines with $L r 24$ and $L r 25$ were immune to 23 and 24 pathotypes, respectively. TcLr-lines with $L r 9$ and $L r 19$ were immune to 19 of 25 pathotypes.

The average value of the virulence of pathotypes from the Akmola region was $61.0 \%$, which is $2.7 \%$ more than the virulence of the eastern population $(58.3 \%)$ and $25 \%$ more than the southeastern population of P. triticina (36\%).

There were some pathotypes with high virulence to $L r$-lines in the eastern population of $P$. triticina. Thus, the virulence of the TKT/Q and TRT/G pathotypes were $81.3 \%$ and $75.0 \%$, respectively. The southeastern leaf rust population contains four pathotypes with virulence from $31.3 \%$ to $43.7 \%$.

Almost all test clones were avirulent to Lr9, Lr19, Lr24, and Lr25. Thatcher isogenic lines with these genes show high efficiency for many of the studied leaf rust pathotypes. Accordingly, the sources of these genes protect spring wheat from many leaf rust pathotypes. Most of the pathotypes were virulent to Tc-lines with Lr1, Lr2a, Lr3ka, Lr11, and Lr30. Isolates differed in their virulence to $L r 3 a, \operatorname{Lr} 3 b g, \operatorname{Lr} 10, \operatorname{Lr} 16, \operatorname{Lr} 17, \operatorname{Lr} 18, \operatorname{Lr} 20, \operatorname{Lr} 26$, and $\operatorname{Lr} 29$ (Table S1).

Some isogenic lines $(\operatorname{Lr} 10, L r 23, L r 26, L r 29)$ in most cases exhibit intermediate resistant reactions $(2,2+)$, which quickly turn into susceptibility during plant development and/or at the slightest change in plant growth conditions. Consequently, the sources of these genes are inappropriate to use in breeding for immunity due to the variability of their resistance response. 
Table 1. Virulence of the 25 pathotypes of P. triticina from different regions of Kazakhstan, determined using a subset of near-isogenic differentials in a Thatcher background.

\begin{tabular}{|c|c|c|c|c|}
\hline \multirow{2}{*}{ Pathotype } & \multirow{2}{*}{ Virulence Formula (Avirulent/Virulent) } & \multicolumn{2}{|c|}{ Response of $\operatorname{Lr}$ Genes (\%) } & \multirow{2}{*}{$\begin{array}{c}\text { Frequencies of } \\
\text { Pathotypes }\end{array}$} \\
\hline & & $\mathbf{R}$ & $\mathrm{S}$ & \\
\hline & East Kazakhstan region (East) & & & \\
\hline KGQ/B & $\operatorname{Lr} 1,9,24,26,17,30,19,20,25,29 / \operatorname{Lr} 2 \mathrm{a}, 2 \mathrm{c}, 3,16,3 \mathrm{ka}, 11$ & 62.5 & 37.5 & 8.5 \\
\hline $\mathrm{TKT} / \mathrm{Q}$ & $\operatorname{Lr} 9,25,29 / \operatorname{Lr} 1,2 \mathrm{a}, 2 \mathrm{c}, 3,16,24,26,3 \mathrm{ka}, 11,17,30,19,20$ & 18.7 & 81.3 & 9.5 \\
\hline $\mathrm{DCN} / \tilde{\mathrm{H}}$ & $\operatorname{Lr} 1,2 \mathrm{a}, 3 \mathrm{a}, 9,16,24,11,30,19,25 / \operatorname{Lr} 2 \mathrm{c}, 26,3 \mathrm{ka}, 17,20,29$ & 62.5 & 37.5 & 8.0 \\
\hline $\mathrm{RCP} / \mathrm{G}$ & $L r 2 c, 9,16,24,11,19,25,29 / L r 1,2 a, 3 a, 26,3 k a, 17,30,20$ & 50.0 & 50.0 & 24.5 \\
\hline $\mathrm{SQT} / \mathrm{Q}$ & $\operatorname{Lr} 3,24,26,25,29 / \operatorname{Lr} 1,2 \mathrm{a}, 2 \mathrm{c}, 9,16,3 \mathrm{ka}, 11,17,30,19,20$ & 31.3 & 68.7 & 14.5 \\
\hline $\mathrm{TGS} / \widehat{G}$ & $\operatorname{Lr} 9,24,26,30,19,25,29 / \operatorname{Lr} 1,2 \mathrm{a}, 2 \mathrm{c}, 3 \mathrm{a}, 16,3 \mathrm{ka}, 11,17,20$ & 43.7 & 56.3 & 8.5 \\
\hline $\mathrm{TRT} / \mathrm{G}$ & Lr24,19,25,29/Lr1,2a,2c,3a,9,16,26,3ka,11,17,30,20 & 25.0 & 75.0 & 12.0 \\
\hline $\mathrm{KHT} / \mathrm{B}$ & $L r 1,9,24,19,20,25,29 / L r 2 \mathrm{a}, 2 \mathrm{c}, 3 \mathrm{a}, 16,26,3 \mathrm{ka}, 11,17,30$ & 43.7 & 56.3 & 8.0 \\
\hline \multirow[t]{2}{*}{$\mathrm{TGT} / \mathrm{G}$} & $\operatorname{Lr} 9,24,26,19,25,29 / \operatorname{Lr} 1,2 \mathrm{a}, 2 \mathrm{c}, 3 \mathrm{a}, 16,3 \mathrm{ka}, 11,17,30,20$ & 37.5 & 62.5 & 6.5 \\
\hline & Average value & 41.7 & 58.3 & 11.1 \\
\hline & Akmola region (North) & & & \\
\hline $\mathrm{TLT} / \mathrm{R}$ & $\operatorname{Lr} 16,24,26,25 / \operatorname{Lr} 1,2 \mathrm{a}, 2 \mathrm{c}, 3,9,3 \mathrm{ka}, 11,17,30,19,20,29$ & 25.0 & 75.0 & 8.0 \\
\hline $\mathrm{RLP} / \mathrm{H}$ & $\operatorname{Lr} 2 \mathrm{c}, 16,24,26,11,19,25 / \operatorname{Lr} 1,2 \mathrm{a}, 3,9,3 \mathrm{ka}, 17,30,20,29$ & 43.7 & 56.3 & 5.0 \\
\hline $\mathrm{CJF} / \mathrm{B}$ & Lr1,2a,2c,9,26,3ka,11,19,20,25,29/Lr3,16,24,17,30 & 68.7 & 31.3 & 9.0 \\
\hline $\mathrm{THT} / \mathrm{J}$ & $\operatorname{Lr} 9,24,19,29 / \operatorname{Lr} 1,2 \mathrm{a}, 2 \mathrm{c}, 3 \mathrm{a}, 16,26,3 \mathrm{ka}, 11,17,30,20,25$ & 25.0 & 75.0 & 12.0 \\
\hline $\mathrm{TGT} / \mathrm{G}$ & $\operatorname{Lr} 9,24,26,19,25,29 / \operatorname{Lr} 1,2 \mathrm{a}, 2 \mathrm{c}, 3 \mathrm{a}, 16,3 \mathrm{ka}, 11,17,30,20$ & 37.5 & 62.5 & 18.0 \\
\hline $\mathrm{TQT} / \mathrm{G}$ & $L r 24,26,19,25,29 / L r 1,2 a, 2 c, 3 a, 9,16,3 \mathrm{ka}, 11,17,30,20$ & 31.3 & 68.7 & 10.0 \\
\hline TGK/G & $\operatorname{Lr} 9,24,26,3 \mathrm{ka}, 19,25,29 / \operatorname{Lr} 1,2 \mathrm{a}, 2 \mathrm{c}, 3 \mathrm{a}, 16,11,17,30,20$ & 43.7 & 56.3 & 8.0 \\
\hline $\mathrm{TBT} / \mathrm{Q}$ & $\operatorname{Lr} 9,16,24,26,25,29 / \operatorname{Lr} 1,2 \mathrm{a}, 2 \mathrm{c}, 3 \mathrm{a}, 3 \mathrm{ka}, 11,17,30,19,20$ & 37.5 & 62.5 & 8.0 \\
\hline $\mathrm{RGT} / \tilde{\mathrm{G}}$ & $L r 2 c, 9,24,26,19,25,29 / L r 1,2 \mathrm{a}, 3 \mathrm{a}, 16,3 \mathrm{ka}, 11,17,30,20$ & 43.7 & 56.3 & 6.0 \\
\hline $\mathrm{TQT} / \mathrm{M}$ & $L r 24,26,20,25 / L r 1,2 \mathrm{a}, 2 \mathrm{c}, 3 \mathrm{a}, 9,16,3 \mathrm{ka}, 11,17,30,19,29$ & 25.0 & 75.0 & 6.0 \\
\hline $\mathrm{SBR} / \mathrm{H}$ & $L r 3 a, 9,16,24,26,17,19,25 / \operatorname{Lr} 1,2 a, 2 c, 3 k a, 11,30,20,29$ & 50.0 & 50.0 & 5.0 \\
\hline \multirow[t]{2}{*}{$\mathrm{THT} / \mathrm{B}$} & $\operatorname{Lr} 9,24,19,20,25,29 / \operatorname{Lr} 1,2 \mathrm{a}, 2 \mathrm{c}, 3,16,26,3 \mathrm{ka}, 11,17,30$ & 37.5 & 62.5 & 5.0 \\
\hline & Average value & 39.1 & 61.0 & 8.3 \\
\hline & Almaty region (Southeast) & & & \\
\hline $\mathrm{JCL} / \mathrm{G}$ & Lr1,3a,9,16,24,11,17,30,19,25,29/Lr2a,2c,26,3ka,20 & 68.7 & 31.3 & 28 \\
\hline $\mathrm{PBN} / \mathrm{C}$ & $L r 2 \mathrm{a}, 9,16,24,26,11,30,19,20,25 / L r 1,2 \mathrm{c}, 3,3 \mathrm{ka}, 17,29$ & 62.5 & 37.5 & 21 \\
\hline $\mathrm{QBQ} / \mathrm{G}$ & $L r 2 c, 3 a, 9,16,24,26,17,30,19,25,29 / L r 1,2 a, 3 k a, 11,20$ & 68.7 & 31.3 & 22 \\
\hline \multirow[t]{2}{*}{ SBP/C } & $L r 3 a, 9,16,24,26,11,19,20,25 / \operatorname{Lr} 1,2 \mathrm{a}, 2 \mathrm{c}, 3 \mathrm{ka}, 17,30,29$ & 56.3 & 43.7 & 29 \\
\hline & Average value & 64.1 & 36.0 & 25.0 \\
\hline
\end{tabular}

R-resistant response of Lr genes to Ptr pathotypes; S-susceptible response of Lr genes to Ptr pathotypes.

\subsection{Seedling Test}

Spring wheat germplasm was evaluated for response to $P$. triticina pathotypes. A complete list of this plant material, its origin, and leaf rust reaction are given in Table 2. The seedling reactions of 30 wheat genotypes to the 5 pathotypes of Ptr differed greatly. The wheat genotypes showed arrays of patterns in their responses to the five pathotypes. The most commercial spring wheat varieties in Kazakhstan were generally susceptible to leaf rust pathotypes. The varieties Stepnaya 62 and Omskaya 37 were resistant to almost all tested pathotypes of leaf rust. Omskaya 36 was resistant to two of the five pathotypes. Avangard, Kazakhstanskaya rannespelaya, and Kazakhstanskaya 25 were resistant to one pathotype of leaf rust. 
Table 2. The results of assessing spring wheat varieties to the pathotypes of $P$. triticina and identification of leaf rust resistance genes.

\begin{tabular}{|c|c|c|c|c|c|c|c|c|c|c|c|c|c|c|c|}
\hline \multirow{3}{*}{ Cultivar Name } & \multirow{3}{*}{ Origin } & \multirow{3}{*}{$\begin{array}{l}\text { Year of } \\
\text { Release }\end{array}$} & \multicolumn{10}{|c|}{ Reaction to Infection with Pathotypes $P$. triticina } & \multirow{2}{*}{\multicolumn{2}{|c|}{$\begin{array}{c}\text { Leaf Rust Severity } \\
\%, \mathrm{RT}\end{array}$}} & \multirow{3}{*}{$\begin{array}{l}\text { Lr Gene (s) Present } \\
\text { Based on Markers }\end{array}$} \\
\hline & & & \multicolumn{2}{|c|}{ QBQ/G } & \multicolumn{2}{|c|}{ SBR/H } & \multicolumn{2}{|c|}{ KHT/B } & \multicolumn{2}{|c|}{ SBP/C } & \multicolumn{2}{|c|}{ THT/B } & & & \\
\hline & & & $\begin{array}{l}\text { 1st } \\
\text { Score }\end{array}$ & $\begin{array}{l}\text { 2nd } \\
\text { Score }\end{array}$ & $\begin{array}{l}\text { 1st } \\
\text { Score }\end{array}$ & $\begin{array}{l}\text { 2nd } \\
\text { Score }\end{array}$ & $\begin{array}{l}\text { 1st } \\
\text { Score }\end{array}$ & $\begin{array}{l}\text { 2nd } \\
\text { Score }\end{array}$ & $\begin{array}{l}\text { 1st } \\
\text { Score }\end{array}$ & $\begin{array}{l}\text { 2nd } \\
\text { Score }\end{array}$ & $\begin{array}{l}\text { 1st } \\
\text { Score }\end{array}$ & $\begin{array}{l}\text { 2nd } \\
\text { Score }\end{array}$ & 2019 & 2020 & \\
\hline Akmola 2 & KZ:Shortandy & 1998 & $4+$ & $4+$ & $\begin{array}{l}\text { 3-Yes we } \\
\text { confirm }\end{array}$ & $4+$ & $3-$ & $4+$ & $4+$ & $4+$ & $3-$ & $4+$ & $20 \mathrm{MR}$ & $10 \mathrm{MR}$ & Lr1 \\
\hline Almaken & KZ:Almaty-KIZ & 2010 & $4+$ & $4+$ & 3 & $4+$ & $3-$ & 4 & 4 & $4+$ & 3 & $4+$ & $70 S$ & $40 \mathrm{MS}$ & Lr1 \\
\hline Albidum 28 & RU:Saratov & 1987 & $3+$ & $4+$ & 3 & $4+$ & $3-$ & 4 & $4+$ & $4+$ & 3 & $4+$ & $40 \mathrm{MS}$ & $30 \mathrm{MS}$ & Lr10 \\
\hline Astana 2 & KZ:Shortandy & 2008 & $4+$ & $4+$ & 4 & $4+$ & 3 & 4 & $3-$ & $4+$ & 3 & $4+$ & $20 \mathrm{MR}$ & $10 \mathrm{MR}$ & Lr1 \\
\hline Avangard & KZ:East-VNIISH & 2005 & 3 & $4+$ & $2-$ & 4 & $3-$ & 4 & $2+3$ & $4+$ & 0 & 0 & $40 \mathrm{MS}$ & $30 \mathrm{MS}$ & none \\
\hline Bayterek & KZ:Shortandy & 2008 & 3 & $4+$ & $2-$ & $4+$ & $2-$ & 3 & 3 & 4 & $3-$ & 4 & $80 S$ & $40 \mathrm{MS}$ & Lr1 Lr28 \\
\hline Zhenis & KZ:Almaty-KIZ & 2006 & 3 & $4+$ & 3 & 4 & $3-$ & 4 & 4 & $4+$ & $3-$ & 4 & $40 \mathrm{MS}$ & $30 \mathrm{MS}$ & Lr1 \\
\hline $\begin{array}{c}\text { Kazakhstanskaya } \\
\text { rannespelaya }\end{array}$ & $\begin{array}{c}\text { KZ:Almaty-KIZ- } \\
\text { Karabalyk }\end{array}$ & 1991 & $3-$ & $4+$ & $2-$ & $4+$ & $3-$ & $4+$ & 3 & $4+$ & 0 & 0 & $20 \mathrm{MS}$ & $10 \mathrm{MR}$ & Lr1 \\
\hline Kazakhstanskaya 10 & KZ:Almaty-KIZ & 1996 & $4+$ & $4+$ & 3 & $4+$ & $3-$ & $4+$ & 4 & $4+$ & $3-$ & $4+$ & $30 \mathrm{MS}$ & $20 \mathrm{MS}$ & none \\
\hline Kazakhstanskaya 25 & KZ:Almaty-KIZ & 1997 & 2 & 2 & $3+$ & $4+$ & 3 & 4 & 4 & $4+$ & $3-$ & $4+$ & $20 \mathrm{MR}$ & $15 \mathrm{MR}$ & $\operatorname{Lr1}$ \\
\hline Karabalykskaya 92 & KZ:Karabalyk & 1997 & $3-$ & $4+$ & $2-$ & 4 & 3 & 4 & $4+$ & $4+$ & 3 & $4+$ & $40 \mathrm{MS}$ & $20 \mathrm{MS}$ & none \\
\hline Karagandunskaya 70 & KZ:Karaganda & 1992 & 0 & 4 & 3 & 4 & 1 & 3 & $3-$ & $4+$ & $3-$ & 4 & $30 \mathrm{MS}$ & $20 \mathrm{MS}$ & Lr1, Lr68 \\
\hline Lyazzat & KZ:East- VNIISH & 2011 & 1 & 4 & $2-$ & $3+$ & $3-$ & 4 & $3+$ & $4+$ & 3 & $4+$ & $60 S$ & $50 S$ & Lr1 \\
\hline Nargiz & KZ:East- VNIISH & 2011 & $3-$ & 4 & 3 & $4+$ & $2+3$ & 4 & $4-$ & $4+$ & 3 & $4+$ & $40 S$ & $30 \mathrm{MS}$ & none \\
\hline Omskaya 36 & RU:Omsk-AC & 2007 & 2 & 2 & 3 & 4 & $3-$ & $4+$ & 2 & 2 & 4 & 4 & $70 S$ & $50 \mathrm{~S}$ & none \\
\hline Pavlodarskaya 93 & KZ:Pavlodar & 1999 & $2-$ & $4-$ & 3 & $4+$ & 3 & $4+$ & $2-$ & $4+$ & 3 & 4 & $90 \mathrm{~S}$ & $30 \mathrm{MS}$ & Lr1 \\
\hline Stepnaya 2 & RU:Saratov & 2010 & 4 & 4 & $3-$ & $4+$ & $3-$ & $4+$ & 3 & $4+$ & $4+$ & $4+$ & $40 \mathrm{MS}$ & $30 \mathrm{MS}$ & Lr1 \\
\hline Ulbinka 25 & KZ:East- VNIISH & 1989 & $2+3$ & $4-$ & $3+$ & $4+$ & 3 & 4 & $3+$ & $4+$ & 3 & 4 & $50 \mathrm{~S}$ & 40MS & none \\
\hline Tselina 50 & KZ:Shortandy & 2010 & 4 & 4 & $4+$ & 4 & 3 & $4+$ & $4+$ & $4+$ & 4 & $4+$ & $30 \mathrm{MS}$ & $90 \mathrm{~S}$ & Lr1 \\
\hline Tselinnaya 3C & KZ:Shortandy & 1996 & 3 & 4 & $4+$ & 4 & $3+$ & $4+$ & $4+$ & $4+$ & $4+$ & $4+$ & $30 \mathrm{MS}$ & $100 S$ & $\operatorname{Lr1}$ \\
\hline
\end{tabular}


Table 2. Cont.

\begin{tabular}{|c|c|c|c|c|c|c|c|c|c|c|c|c|c|c|c|}
\hline \multirow{3}{*}{ Cultivar Name } & \multirow{3}{*}{ Origin } & \multirow{3}{*}{$\begin{array}{l}\text { Year of } \\
\text { Release }\end{array}$} & \multicolumn{10}{|c|}{ Reaction to Infection with Pathotypes $P$. triticina } & \multirow{2}{*}{\multicolumn{2}{|c|}{$\begin{array}{c}\text { Leaf Rust Severity } \\
\%, \mathrm{RT}\end{array}$}} & \multirow{3}{*}{$\begin{array}{l}\text { Lr Gene (s) Present } \\
\text { Based on Markers }\end{array}$} \\
\hline & & & \multicolumn{2}{|c|}{$\mathrm{QBQ} / \mathrm{G}$} & \multicolumn{2}{|c|}{ SBR/H } & \multicolumn{2}{|c|}{ КHT/B } & \multicolumn{2}{|c|}{ SBP/C } & \multicolumn{2}{|c|}{ THT/B } & & & \\
\hline & & & $\begin{array}{c}\text { 1st } \\
\text { Score }\end{array}$ & $\begin{array}{l}\text { 2nd } \\
\text { Score }\end{array}$ & $\begin{array}{l}1 \text { 1st } \\
\text { Score }\end{array}$ & $\begin{array}{l}\text { 2nd } \\
\text { Score }\end{array}$ & $\begin{array}{c}1 \text { 1st } \\
\text { Score }\end{array}$ & $\begin{array}{l}\text { 2nd } \\
\text { Score }\end{array}$ & $\begin{array}{c}\text { 1st } \\
\text { Score }\end{array}$ & $\begin{array}{l}\text { 2nd } \\
\text { Score }\end{array}$ & $\begin{array}{c}1 \text { 1st } \\
\text { Score }\end{array}$ & $\begin{array}{l}\text { 2nd } \\
\text { Score }\end{array}$ & 2019 & 2020 & \\
\hline $\begin{array}{l}\text { Shortandinskaja } \\
\text { uluchshennaja } 95\end{array}$ & KZ:Shortandy & 2006 & 2 & $3+$ & $1+2$ & 4 & $2+3$ & $4+$ & $1+2$ & 4 & $2+3$ & 3 & 40MS & $100 \mathrm{~S}$ & $\operatorname{Lr} 28$ \\
\hline Erythrospermum 35 & KZ:Karabalyk & 1991 & 3 & $4+$ & 4 & 4 & 3 & $4+$ & 4 & $4+$ & 4 & $4+$ & $50 S$ & 30MS & Lr1, Lr68 \\
\hline Erythrospermum 841 & RU:Saratov & 1942 & 3 & $4+$ & $4+$ & 4 & 3 & $4+$ & $4+$ & $4+$ & $3+$ & 4 & $60 S$ & $40 \mathrm{MS}$ & Lr1 \\
\hline Omskaya 37 & RU:Omsk-AC & 2016 & 0 & 2 & 3 & 3 & 0 & $2+$ & 3 & $3+$ & 0 & 0 & 0 & $10 \mathrm{R}$ & Lr1, Lr10, Lr19, Lr26 \\
\hline Tertsiya & RU:Omsk-AC & 1995 & 2 & $3+$ & 3 & 4 & $3-$ & 4 & $3-$ & $4+$ & $2+3$ & 4 & 0 & $10 \mathrm{R}$ & $\operatorname{Lr1}, \operatorname{Lr} 9$ \\
\hline Chelyaba jubilejnaja & RU:Chelyabinsk & 2010 & $3-$ & 4 & 3- & $4+$ & 3 & $4+$ & $3-$ & 4 & 3 & 4 & 0 & $15 \mathrm{MR}$ & $\operatorname{Lr1}, \operatorname{Lr} 9$ \\
\hline Saratovskaya 29 & Ru:Saratov & 1957 & 3 & $4+$ & 4 & $4+$ & 3 & $4+$ & $4+$ & $4+$ & $4+$ & $4+$ & $60 S$ & $50 S$ & $\operatorname{Lr} 1, \operatorname{Lr} 10, \operatorname{Lr} 28$ \\
\hline $\begin{array}{l}\text { Morocco (susceptible } \\
\text { check) }\end{array}$ & Morocco & - & 4 & $4+$ & 4 & $4+$ & 4 & $4+$ & $4+$ & $4+$ & $4+$ & $4+$ & $100 \mathrm{~S}$ & $90 \mathrm{~S}$ & none \\
\hline
\end{tabular}

Abbreviations: SVT—cultivar candidate submitted to the state variety testing; RT—reaction type. 
The five pathotypes showed arrays of virulence patterns across 30 wheat genotypes (Table 2). Based on infection type across 30 genotypes, $\mathrm{SBR} / \mathrm{H}$ was the most virulent, followed by SBP/C and KHT/B. The pathotypes THT/B and QBQ/G were the least virulent. The analysis based on reactions of all five pathotypes showed that Stepnaya 62 and Omskaya 37 were the most stable resistant genotypes.

\subsection{Field Evaluation}

Arrays of variation for resistance to leaf rust under field conditions (Table 2) were present. Most wheat varieties $(73.33 \%)$ were susceptible to leaf rust in the field. Among 30 genotypes, 7 (Akmola 2, Astana 2, Kazakhstanskaya 25, Stepnaya 62, Omskaya 37, Tertsiya, and Chelyaba jubilejnaja) were considered as resistant ( $\leq 20 \%$ disease severity) in the adult plant stage under field conditions in Kazakhstan (Table 2). Four genotypes showed $\leq 5 \%$ disease severity in both years. Among the genotypes with the most stable resistance in the seedling stage, Stepnaya 62 and Omskaya 37 were resistant in the adult plant stage under field conditions in both years.

\subsection{Identification of Leaf Rust Resistance Genes Using Molecular Markers}

The occurrence of known Lr genes in the 30 wheat cultivars is shown in Table 2. Molecular screening of these genotypes showed contrasting differences in the frequencies of these genes. The most frequent $L r$ gene, identified in the material studied individually or in combination, was Lr1. The expected marker fragment associated with Lr1 was found in 22 of the 30 cultivars, including Akmola 2, Almaken, Astana, Astana 2, Bayterek, Zhenis, Kazakhstanskaya rannespelaya, Kazakhstanskaya 19, Kazakhstanskaya 25, Karagandunskaya 70, Lyazzat, Pavlodarskaya 93, Stepnaya 2, Tselina 50, Tselinnaya 3C, Erythrospermum 35, Erythrospermum 841, Stepnaya 62, Omskaya 37, Tertsiya, Chelyaba jubilejnaja, and Saratovskaya 29. The marker for $\operatorname{Lr} 9$ was found in two Russian cultivars, Tertsiya and Chelyaba jubilejnaja, in this study. The marker linked to Lr10 was found in three Russian cultivars, Albidum 28, Omskaya 37, and Saratovskaya 29. The 1BL.RS translocation carrying Lr26 and Lr19 were present in one Russian cultivar, Omskaya 37. Two single cultivars separately carried Lr26 and Lr34, while Lr37 was not detected in any genotypes in this study. The marker linked to Lr28 was found in four stocks (Bayterek, Kazakhstanskaya 19, Saratovskaya 29, and Shortandinskaya uluchshennaja 95). The marker linked to Lr34 was found only in h cv. Kazakhstanskaya 19. Cultivars with the genes Lr37 and Lr19 were not identified. The marker closely linked to Lr68 was found only in two crs. Astana and Karagandinskaya 70.

Two cultivars had the highest number of resistance genes: Omskaya 37 (Lr1, Lr10, Lr19, and Lr26) and Kazakhstanskaya 19 (Lr1, Lr28, Lr34), although Lr1 was not effective against the most leaf rust pathotypes studied in this research. Two gene combinations were detected in Kazakh cvs. Erythrospermum 35 (Lr1, Lr68) and Astana (Lr1, Lr68). From all investigated cultivars, six Kazakh wheats (Avangard, Kazakhstanskaya 10, Karabalykskaya 92, Nargiz, Omskaya 36, and Ulbinka 25) and susceptible cultivar Morocco failed to show evidence of any of the nine $\mathrm{Lr}$ markers tested.

\section{Discussion}

Leaf rust is a perennial problem for spring and winter wheat in Central Asia, including Kazakhstan [14,15,35], and Ptr populations are diverse and highly virulent [27,30].

Previous studies have reported variations in Ptr populations in Kazakhstan $[4,27,30]$. It is therefore necessary to periodically evaluate resistant cultivars and advanced breeding lines against $P t r$ races in order to monitor resistance breakdown and plan the replacement of susceptible cultivars with resistant ones.

This study provides additional information by presenting 25 diverse Ptr races with wide virulence patterns on 16 international differentials of leaf rust and 30 genetically diverse genotypes in both seedling and adult plant stages. Each of the 25 races showed diverse reaction patterns on the wheat genotypes, with virulence varying from resistant to 
highly susceptible. $L r 25$ and $L r 24$ were the most effective genes in Kazakhstan. In this study, the isogenic lines with $L r 24$ and $L r 25$ were immune to 23 and 24 pathotypes, respectively. Tc $L r$-lines with $L r 9$ and $L r 19$ were immune to 19 of 25 pathotypes from Kazakhstan. Most of the pathotypes were avirulent to $L r 9, L r 19, \operatorname{Lr} 24$, and $\operatorname{Lr} 25$ and virulent to $L r 1, \operatorname{Lr} 2 a$, $L r 3 k a, L r 11$, and $L r 30$. The study of the virulence of the Russian South Ural population of P. triticina showed that all isolates were avirulent to Tc-lines with gene Lr16, Lr19, Lr24, $L r 28$, and $L r 29$ and virulent to Lr1, Lr3a, Lr3bg, Lr3ka, Lr14a, Lr14b, Lr17, and Lr18 [30]. This suggests that at least two genes ( $L r 19$ and Lr24) have been found to be effective against pathogen populations from both Kazakhstan and Russia.

The number of genotypes showed high levels of seedling resistance to each of the 5 Ptr races, thus confirming genotypic diversity. Two genotypes (Stepnaya 62 and Omskaya 37) were highly resistant to almost all five tested Ptr pathotypes, while Omskaya 36 was resistant to more than two races. Therefore, Stepnaya 62, Omskaya 37, Avangard, Kazakhstanskaya rannespelaya, and Kazakhstanskaya 25 were identified as the most stable genotypes for seedling resistance. Omskaya 37 also showed a stable type of reaction at the seedling stage to Russian isolates [28]. However, most of the varieties from Kazakhstan were susceptible in the seedling stage.

In previous studies, the sources of $L r$ resistance genes $(\operatorname{Lr} 19, L r 26, L r 37, L r 34, L r 1$, Lr26, Lr34, Lr10, Lr37, Lr19, and Lr68 genes) were identified in winter wheat breeding material [4,36-38]. In this research, molecular screening of spring wheat cultivars showed contrasting differences in the frequencies of nine important $L r$ genes. Among the 30 entries, 22 carried leaf rust resistance gene $L r 1,6$ had Lr19, 2 had Lr9, and Lr68, Lr10, and Lr28 were found in 3 and 4 cultivars, respectively. Two single cultivars separately carried $L r 26$ and Lr34, while Lr37 was not detected in any genotypes in this study. Field evaluation demonstrated that the most frequent Lr1 gene to be ineffective. Kazakhstanskaya 19 and Omskaya 37 had the highest number of resistance genes, three and four $L r$ genes, respectively. Two gene combinations ( $L r 1$ and $L r 68$ ) were detected in Erythrospermum 35 and Astana.

The wheat genotypes from Kazakhstan and Russia differed greatly in leaf rust severity recorded at the adult plant stage in the field in Kazakhstan. This supports previous reports on varietal resistance and variation among Ptr populations in Kazakhstan [27] and in Russia [30]. However, a high genetic similarity was shown in virulence and phenotypic composition between the Omsk (Russia) and North Kazakhstan [28]. This indicates the possibility of joint breeding programs to improve leaf rust resistance in these countries. Several cultivars (Stepnaya 62, Omskaya 37, Avangard, Kazakhstanskaya rannespelaya, and Kazakhstanskaya 25) showed low leaf rust severity, suggesting their potential value as sources of resistance. The resistance of Omskaya 37 was due to the rye translocation 1AL.1RS in combination with ineffective Lr1 and Lr10 and, possibly, by the presence of unknown genes. Kazakhstanskaya 19 showed field resistance provided by partial resistance gene Lr34 in combination with Lr1, Lr28. These findings support previous reports that leaf rust resistance improved wheat germplasm are becoming increasingly available in Kazakhstan [4,14].

A number of varieties (Akmola 2, Chelyaba jubileynaya, Astana 2, and Kazakhstanskaya 19) were susceptible in the seedling stage but moderately resistant in the adult plant stage. Such varieties are valuable in terms of potential sources of adult plant resistance [39]. If the presence of both seedling stage resistance and adult plant resistance (APR) and only APR represent major and minor gene control of resistance, respectively, the set of 30 genotypes of this study are indicative of both types of resistance.

The Ptr population in Kazakhstan is diverse, as indicated by the range of virulence shown by the five different races analyzed in this study. Wheat cultivars possess a range of variability for response to Ptr races, and a number of genotypes differed in their level of disease severity in Kazakhstan, suggesting that Ptr populations differ in various regions of Kazakhstan. This study identified some wheat genotypes highly resistant to leaf rust that may contribute to the improvement of leaf rust resistance. The cultivation of new 
leaf rust-resistant varieties could help reduce disease epidemics in Kazakhstan. Resistant genotypes could also be used as improved parents in crossing programs to develop new varieties.

\section{Materials and Methods}

\subsection{Plant Material}

The object of the study was represented by a collection of 30 spring wheat Triticum aestivum entries, including 22 registered cultivars from Kazakhstan and 8 cultivars from Russia, which were evaluated for Puccinia triticina resistance in greenhouse studies and field experiments. This germplasm is produced or used in breeding programs of Kazakhstan. The highly susceptible control cultivar Morocco as well as the near-isogenic lines (NILs) of $\mathrm{cv}$. Thatcher was also used in both seedling and field tests.

\subsection{Experimental Site}

Evaluation of field resistance to leaf rust was carried out under conditions of the Kazakh Research Institute of Agriculture and Crop Production (KazNIIZiR), (Almalybak, $43^{\circ} 13^{\prime} 09^{\prime \prime} \mathrm{N}, 76^{\circ} 36^{\prime} 17^{\prime \prime} \mathrm{E}$, Almaty region) in Southeast Kazakhstan, Almaty region, during 2019 and 2020 cropping seasons. Experiments were conducted with a completely randomized design with two replicates in $1 \mathrm{~m}^{2}$. The leaf rust susceptible cultivar Morocco was planted in every 10th row and as a spreader border around the nursery to ensure uniform infection. Fertilizer treatments, 60 and $30 \mathrm{~kg} / \mathrm{ha}$ of $\mathrm{N}$ and $\mathrm{P}_{2} \mathrm{O}_{5}$, respectively, and other management practices corresponded to those normally recommended for the region [40]. Annual rainfall ranged from 332 to $644 \mathrm{~mm}$ during the two years. Experimental plants were sown in $1 \mathrm{~m}^{2}$ plots in mid-April every two experimental years. Weather conditions in Almaty in 2019 and in 2020 were favorable for the development of leaf rust, and the infection on susceptible checks reached $20 \mathrm{~S}$ and $40 \mathrm{~S}$, respectively; however, there was a severe late development of leaf rust reaching $80 \%$ on susceptible check Morocco. The growing seasons were favorable for pathogen infection and disease development. Mean daily temperature and relative humidity showed similar trends in both years. The average maximum air temperature for mid-May in 2019 and 2020 reached 31.3 and $32.5^{\circ} \mathrm{C}$, respectively. From April to June 2019 , the mean daily temperature was $11.4,16.6$, and $21.6^{\circ} \mathrm{C}$, respectively, and in 2020, 11.4, 16.6, and $21.8^{\circ} \mathrm{C}$. From April to June 2019, the monthly rainfalls and average relative humidity $(\mathrm{RH})$ were 168,39 , and $72 \mathrm{~mm}$, and $59.5 \%$, respectively, and in 2020, 140, 74, and $30 \mathrm{~mm}$, and 57.3\% (www.pogodaiklimat.ru/monitor.php accessed 15 June 2021), conditions highly conducive for leaf rust infection and development.

\subsection{Race Identification}

Race identification was performed under controlled greenhouse conditions at the Research Institute for Biological Safety Problems (RIBSP), Gvardeysky, Zhambyl region, Kazakhstan.

Leaf samples infected with leaf rust Puccinia triticina were randomly collected during the main spring wheat-growing season in East Kazakhstan, Akmola, and Almaty regions of Kazakhstan. Eighty to 100 rust-infected leaves with sporulating pustules were collected from the research stations and fields of farmers from susceptible cultivars (Morocco, Pmayat Azieva, etc.). The diseased leaf samples were pressed in the folds of newspaper, placed in an envelope, and stored at $4{ }^{\circ} \mathrm{C}$ until further analysis.

The virulence codes for the isolates were based on the three-letter nomenclature of Long and Kolmer (1989) [41], with the addition of four sets of four differential lines, for a total of four letters that describe virulence to 16 differentials. Virulence phenotypes determined on the set of 16 differential lines were binary encoded with 0 and 1 for avirulence and virulence, respectively. Set 1: Lr1 (RL6003), Lr2a (RL6000), Lr2c (RL6047), and Lr3 (RL6002); set 2: Lr9 (RL6010), Lr16 (RL6005), Lr24 (RL 6064), and Lr26 (6078); set 3: Lr3ka (RL6007), Lr11 (RL6053), Lr17 (RL6008), and Lr30 (RL6049); set 4: Lr10 (RL6004), Lr18 (RL6009), Lr21 (RL6043), Lr23 (RL6012). Cultivar Thatcher was included as a suscep- 
tible control. Reaction types of 16 differentials were encoded and designated by a letter using the hexadecimal code according to the corresponding binary quadruple. Then each isolate was given a four-letter code (one letter for each set of four differentials), as adapted from the North American nomenclature for virulence in Puccinia triticina [41]. Infection types (IT) of the twenty-five isolates to 16 Thatcher lines that are near-isogenic for leaf rust resistance genes are given in Table 1 and avirulence/virulence profiles.

\subsection{Multiplication and Preservation of Inoculum}

The inoculum of Puccinia triticina was multiplied and maintained on the susceptible cultivar Morocco. Seeds of Morocco were sown in $11 \times 11 \times 15 \mathrm{~cm}$ plastic pots and placed at room temperature until germination. Upon germination, seedlings were dislocated to the glasshouse under temperatures of $25-30^{\circ} \mathrm{C}$ and $19-21^{\circ} \mathrm{C}$ during day and night, respectively. The two-leaf stage seedlings of Morocco were disinfected with Maleic hydrazide (5 $\mathrm{mg}$ in $50 \mathrm{~mL}$ of water per pot) [42] and inoculated with spores from the infected leaf samples. Four pots of Morocco (five plants per pot) were inoculated with urediniospores from individual rust samples. Inoculated seedlings were incubated in a dew chamber for $24 \mathrm{~h}$ at $18-20{ }^{\circ} \mathrm{C}$ and $90 \%$ humidity before being dislocated to the glasshouse at temperatures of $18-24{ }^{\circ} \mathrm{C}$ (day) and $19-21{ }^{\circ} \mathrm{C}$ (night). Pustules of leaf rust appeared on the leaves 8-10 days after inoculation, from which inoculum was collected on the 14th day using a mechanical cyclone collector in a zero-size capsule. The inoculum was then preserved in a vacuum glass vial and later transferred to a refrigerator $\left(+4^{\circ} \mathrm{C}\right)$ until further use. A separate collector was used for each isolate and multiplication of culture. Spore collection, storage, and reproduction were then conducted in accordance with the methods of Roelfs et al. [43]. Spores of P. triticina were used to determine the pathotypes of leaf rust isolated from wheat leaves in the different regions of Kazakhstan.

\subsection{Single Spore Culture}

Morocco seedlings (8-9 days old) were inoculated by spraying the urediniospores previously increased and suspended in light paraffin mineral oil (70 ether: 30 oil). Plants were dried for $1 \mathrm{~h}$ before they were placed in a dew chamber overnight at $18-20^{\circ} \mathrm{C}$ and then transferred to the greenhouse, where temperatures were maintained at $18-24^{\circ} \mathrm{C}$ and $19-21{ }^{\circ} \mathrm{C}$ during the day and night, respectively. Seven days after inoculation, leaves were trimmed with scissors so that just a single uredium remained on the trimmed upper edge of the leaves and preserved with purity [43].

\subsection{Virulence Analysis}

To study the resistance of wheat germplasm, the pathotypes representing different regions ( 1 pathotype from the east, 2 from the north, 2 from the southeast) and possessing approximately average virulence to isogenic lines were used. Seedlings were grown in a greenhouse at $18-20^{\circ} \mathrm{C}$, with $16 \mathrm{~h}$ of supplementary lighting. The seedlings were inoculated with individual $P$. triticina isolates with virulence phenotypes $Q B Q / G, S B R / H$, $\mathrm{KHT} / \mathrm{B}, \mathrm{SBP} / \mathrm{C}$, and THT/B $7 \mathrm{~d}$ after planting when the primary leaves were fully emerged. Urediniospores of each of 25 isolates $\left(5 \times 10^{3}\right.$ spores) were spray inoculated onto a differential host series consisting of 16 wheat single-gene near-isogenic lines known to possess resistance genes $(L r)$ in a Thatcher genetic background [41]. The inoculated seedlings were air-dried for at least $30 \mathrm{~min}$ and were then placed overnight in a mist chamber at $18{ }^{\circ} \mathrm{C}$ and $100 \% \mathrm{RH}$. After a period of $12 \mathrm{~h}$ of high humidity, inoculated differential lines were placed in a temperature-controlled climatic chamber $\left(20 \pm 2{ }^{\circ} \mathrm{C}, 16 \mathrm{~h}\right.$ light $/ 8 \mathrm{~h}$ dark $)$. IT was scored on the 0 to 4 scale 10-12 d after inoculation [44]. IT 0 had no hypersensitive flecks, necrosis, or uredinia, IT ";" had distinct hypersensitive flecks; IT 1 had small uredinia surrounded by necrosis; IT 2 had small uredinia surrounded by distinct chlorosis; IT 3 had moderate size uredinia without distinct chlorosis, and IT 4 had large uredinia without distinct chlorosis, with larger and smaller uredinia for each IT were indicated by appending + or - , respectively. Isolates with infection types $0-2$ and 3-4 were assumed to be avirulent 
and virulent, respectively. Leaf rust resistance gene postulations were determined based on the similarity of the Thatcher line IT to the entry, as described in Oelke and Kolmer (2004) [45].

The wheat germplasm was evaluated for $L r$ genes using similar methods as described above. Plant reaction to leaf rust at the seedling stage was evaluated to the same five P. triticina isolates QBQ/G, SBR/H, KHT/B, SBP/C, and THT/B.

\subsection{Field Evaluation of Adult Plant Resistance}

Field plots were inoculated with mixed races of Ptr obtained from 80 to 100 random infected leaf samples collected from the main spring wheat-growing areas of Kazakhstan. Sampling of spores, their storage, and reproduction was carried out according to the methods of Roelfs et al. [43]. The inoculum was multiplied in the greenhouse on cultivar Morocco, and the collected urediniospores were inoculated by a spore: talc mixture (1:100, $20 \mathrm{mg} / \mathrm{m}^{2}$ ) applied in the tillering stage in spring.

Infection type and severity data were recorded on flag leaves in late May and early June when plots were at boot and milk stages, respectively. The time of second evaluation was also determined when rust severity on the susceptible control Morocco reached $60-80 \%$. Scoring of leaf rust symptoms was performed according to the method developed at the CIMMYT [43]. The five infection types (IT) were: 0 -immune; $\mathrm{R}$-resistant; MR - moderately resistant; MS — moderately susceptible; and S-susceptible. Partial resistance in the field was evaluated at boot and milk stages, respectively, using the modified Cobb scale [46]. Leaf rust severities were recorded using three replications, and the means of the replicated data were calculated.

\subsection{DNA Extraction and Detection of Lr Genes with Molecular Markers}

Genomic DNA was extracted from fresh leaves of single plants at the two-leaf seedling stage for each genotype using the CTAB method [47]. The presence of molecular markers to resistance genes Lr1 (pTAG), Lr9 (J13), Lr10 (Fi.2245/Lr10-6/r2), Lr19/Sr25 (PSY1-EF), Lr26/Sr31/Yr9/Pm (SCM9), Lr28 (Wmc313), Lr34/Sr57/Yr18 (csLV34), Lr37/Sr38/Yr17 (Ventriup/LN2), and Lr68 (csGS) was determined as described by Feuillet et al. (1995) [48], Schachermayr et al. (1994) [49], Schachermayr et al. (1997) [50], Zhang and Dubcovsky (2008) [51], Weng et al. (2007) [52], Vikal et al. (2004) [53], Lagudah et al. (2006) [54], Helguera et al. (2003) [55] and Herrera-Foessel et al. (2012) [56] (Table S2). Primers and annealing temperature conditions of polymerase chain reaction (PCR) were carried out as described for each $\mathrm{Lr}$ gene in the references (Table S1). PCR reactions were performed in a Bio-Rad T100TM Thermal Cycler (Bio-RAD, Hercules, CA, USA). The PCR mixture $(25 \mu \mathrm{L})$ contained $2.5 \mu \mathrm{L}$ of genomic DNA $(30 \mathrm{ng}), 1 \mu \mathrm{L}$ of each primer $(1 \mathrm{pM} / \mu \mathrm{L})($ Sigma Aldrich, St. Louis, MO, USA), $2.5 \mu \mathrm{L}$ of dNTP mixture (2.5 mM, dCTP, dGTP, dTTP and dATP aqueous solution) (ZAO Sileks, Russia), $2.5 \mu \mathrm{L} \mathrm{MgCl} 2$ (25 mM), $0.2 \mu \mathrm{L}$ Taq polymerase ( 5 units $\mu \mathrm{L}$ ) (ZAO Sileks, Russia), $2.5 \mu \mathrm{L}$ 10X PCR buffer and $12.8 \mu \mathrm{L}$ ddH20. PCR amplification was performed with a Mastercycler (Eppendorf, Hamburg, Germany) with initial denaturation at $94{ }^{\circ} \mathrm{C}$ for $3 \mathrm{~min}, 45$ cycles: $94^{\circ} \mathrm{C}$ for $1 \mathrm{~min}$, annealing at $60{ }^{\circ} \mathrm{C}$ for $1 \mathrm{~min}, 72{ }^{\circ} \mathrm{C}$ for $2 \mathrm{~min}$, and final elongation at $72{ }^{\circ} \mathrm{C}$ for $10 \mathrm{~min}$. The amplification products were separated on $2 \%$ agarose gel in TBE buffer ( $45 \mathrm{mM}$ Tris-borate, $1 \mathrm{mM}$ EDTA, pH 8) [57] with the addition of ethidium bromide. To determine the length of the amplification fragment, a 100-bp DNA ladder (Fermentas, Vilnius, Lithuania) was included. Results were visualized using the Gel Documentation System (Gel Doc XR+, BIO-RAD, Hercules, CA, USA).

Supplementary Materials: The following are available online at https:/ / www.mdpi.com/article/10 .3390/plants10071484/s1, Table S1: Seedlings reaction of Thatcher Lr genes isogenic lines to eight Prt pathotypes, Kazakhstan, Table S2: Markers and primers used to identify the presence of Lr genes in wheat germplasm. 
Author Contributions: A.K. and S.R. conceived the manuscript and designed the research. A.K. and S.R. analyzed the data and wrote the manuscript. M.A., M.K., A.M., Z.K., D.Z. and A.B. generated the phenotypic and genotyping data. All authors reviewed the manuscript. All authors have read and agreed to the published version of the manuscript.

Funding: This work is supported by the Project of the Ministry of Education and Science of the Republic of Kazakhstan, Grant №AP09258991 “Mapping of loci of quantitative traits associated with resistance to leaf rust in the population of recombinant inbred wheat lines from Kazakhstan" (2021-2023).

Institutional Review Board Statement: Not applicable.

Informed Consent Statement: Not applicable.

Data Availability Statement: Not applicable.

Acknowledgments: Editing assistance from D. Murzabekov is appreciated.

Conflicts of Interest: Authors declare no conflict of interest.

\section{References}

1. Morgounov, A.; Abugalieva, A.; Martynov, S. Effect of climate change and variety on long-term variation of grain yield and quality in winter wheat in kazakhstan. Cereal Res. Commun. 2014, 42, 163-172. [CrossRef]

2. Kokhmetova, A.A.; Morgounov, S.; Rsaliev, A.; Rsaliev, G.; Yessenbekova, M.; Typina, L. Wheat germplasm screening for stem rust resistance using conventional and Rust resistance in wheat molecular techniques. Czech J. Genet. Plant Breed. 2011, 47, 146-154. [CrossRef]

3. Kokhmetova, A.; Sharma, R.; Rsaliyev, S.; Galymbek, K.; Baymagambetova, K.; Ziyaev, Z.; Morgounov, A. Evaluation of Central Asian wheat germplasm for stripe rust resistance. Plant Genet. Resour. 2018, 16, 178-184. [CrossRef]

4. Kokhmetova, A.; Madenova, M.; Purnhauser, L.; Kampitova, G.; Urazaliev, R.; Yessimbekova, M. Identification of leaf rust resistance genes in wheat cultivars produced in Kazakhstan. Cereal Res. Commun. 2016, 44, 240-250. [CrossRef]

5. Rsaliyev, A.S.; Rsaliyev, S.S. Principal approaches and achievements in studying race composition of wheat stem rust. Vavilov J. Genet. Breed. 2018, 22, 967-977. [CrossRef]

6. Kokhmetova, A.M.; Ali, S.; Sapakhova, Z.; Atishova, M.N. Identification of genotypes-carriers of resistance to tan spot Ptr ToxA and Ptr ToxB of Pyrenophora tritici-repentis in common wheat collection. Vavilov J. Genet. Breed. 2018, 22, 978-986. [CrossRef]

7. Kokhmetova, A.; Kremneva, O.; Volkova, G.; Atishova, M.; Sapakhova, Z. Evaluation of wheat cultivars growing in Kazakhstan and Russia for resistance to tan spot. J. Plant Pathol. 2017, 99, 161-167. [CrossRef]

8. Kokhmetova, A.M.; Atishova, M.N.; Madenova, A.K.; Kumarbayeva, M.T. Genotyping of wheat germplasm for resistance to toxins of tan spot Pyrenophora tritici-repentis. J. Biotechnol. 2019, 305, S53. [CrossRef]

9. Kokhmetova, A.M.; Kovalenko, N.M.; Kumarbaeva, M.T. Pyrenophora tritici-repentis population structure in the Republic of Kazakhstan and identification of wheat germplasm resistant to tan spot. Vavilov J. Genet. Breed. 2020, 24, 722-729. [CrossRef]

10. Kokhmetova, A.; Sehgal, D.; Ali, S.; Atishova, M.; Kumarbayeva, M.; Leonova, I.; Dreisigacker, S. Genome-Wide Association Study of Tan Spot Resistance in a Hexaploid Wheat Collection from Kazakhstan. Front. Genet. 2021, 11, 581214. [CrossRef]

11. Kokhmetova, A.; Kumarbayeva, M.; Atishova, M.; Nehe, A.; Riley, I.T.; Morgounov, A. Identification of high-yielding wheat genotypes resistant to Pyrenophora tritici-repentis (tan spot). Euphytica 2021, 217, 97. [CrossRef]

12. Kolmer, J.A.; Herman, A.; Ordoñez, M.E.; German, S.; Morgounov, A.; Pretorius, Z.; Visser, B.; Anikster, Y.; Acevedo, M. Endemic and panglobal genetic groups, and divergence of hostassociated forms in worldwide collections of the wheat leaf rust fungus Puccinia triticina as determined by genotyping by sequencing. Heredity 2020, 124, 397-409. [CrossRef]

13. Savary, S.; Willocquet, L.; Pethybridge, S.J.; Esker, P.; McRoberts, N.; Nelson, A. The global burden of pathogens and pests on major food crops. Nat. Ecol. Evol. 2019, 3, 430-439. [CrossRef] [PubMed]

14. Koyshibaev, M.K. Diseases of Wheat; FAO: Ankara, Turkey, 2018; p. 365.

15. Morgounov, A.; Rosseeva, L.; Koyshibayev, M. Leaf rust of spring wheat in Northern Kazakhstan and Siberia: Incidence, virulence, and breeding for resistance. Aust. J. Agric. Res. 2007, 58, 847-853. [CrossRef]

16. Chen, X.M. Epidemiology and control of stripe rust (Puccinia striiformis f. sp. tritici) on wheat. Can. J. Plant Pathol. 2005, 27, 314-337. [CrossRef]

17. Kolmer, J.A. Genetics of resistance to wheat leaf rust. Annu. Rev. Phytopathol. 1996, 34, 435-455. [CrossRef] [PubMed]

18. Singh, R.P.; Huerta-Espino, J.; William, H.M. Genetics and breeding for durable resistance to leaf and stripe rusts in wheat. Turk. J. Agric. For. 2005, 29, 121-127. [CrossRef]

19. McIntosh, R.A.; Dubcovsky, J.; Rogers, W.J.; Morris, C.; Xia, X.C. Catalogue of Gene Symbols for Wheat: 2017 Supplement. Available online: https://shigen.nig.ac.jp/wheat/komugi/genes/macgene/supplement2017.pdf (accessed on 16 June 2020).

20. Singh, S.; Bowden, R.L. Molecular mapping of adult-plant race-specific leaf rust resistance gene Lr12 in bread wheat. Mol. Breed. 2011, 28, 37-142. [CrossRef] 
21. Ellis, J.G.; Lagudah, E.S.; Spielmeyer, W.; Dodds, P.N. The past, present and future of breeding rust resistant wheat. Front. Plant Sci. 2014, 5, 641-654. [CrossRef]

22. Krattinger, S.G.; Lagudah, E.S.; Spielmeyer, W.; Singh, R.P.; Huerta-Espino, J.; McFadden, H.; Bossolini, E.; Selter, L.L.; Keller, B. A putative $\mathrm{ABC}$ transporter confers durable resistance to multiple fungal pathogens in wheat. Science 2009, 323, $1360-1363$. [CrossRef] [PubMed]

23. Moore, J.W.; Herrera-Foessel, S.; Lan, C.; Schnippenkoetter, W.; Ayliffe, M.; Huerta-Espino, J.; Lillemo, M.; Viccars, L.; Milne, R.; Periyannan, S.; et al. Recently evolved hexose transporter variant confers resistance to multiple pathogens in wheat. Nat. Genet. 2015, 47, 1494-1498. [CrossRef]

24. Fu, D.; Uauy, C.; Distelfeld, A.; Blechl, A.; Epstein, L.; Chen, X.; Sela, H.; Fahima, T.; Dubcovsky, J. A kinase-START gene confers temperature- dependent resistance to wheat stripe rust. Science 2009, 323, 1357-1360. [CrossRef] [PubMed]

25. Feuillet, C.; Travella, S.; Stein, N.; Albar, L.; Nublat, A.; Keller, B. Map- based isolation of the leaf rust disease resistance gene Lr10 from the hexaploid wheat (Triticum aestivum L.) genome. Proc. Natl. Acad. Sci. USA 2003, 100, 15253-15258. [CrossRef]

26. Koishybaev, M.K.; Zhanarbekova, A.B.; Kokhmetova, A.M.; Rsaliev, S.S. Genetic study of wheat resistance to leaf rust. Izv. NAS RK. Ser. Biol. Med. 2010, 6, 10-15.

27. Rsaliev, S.; Kokhmetova, A.M.; Sedlovsky, A.; Rsaliev, A.; Tileubaeva, Z.S.; Tyupina, L.N.; Esenbekova, G.T.; Atishova, M.N.; Agabaeva, A.C. Catalog of Varieties and Samples of Wheat with Genes for Resistance to Leaf Rust: Guidelines; Guidelines: Almaty, Kazakhstan, 2011; p. 100.

28. Gultyaeva, E.I.; Kovalenko, N.M.; Shamanin, V.P.; Tyunin, V.A.; Shreyder, E.R.; Shaydayuk, E.L.; Morgunov, A.I. Population structure of leaf pathogens of common spring wheat in the West Asian regions of Russia and North Kazakhstan in 2017. Vavilov J. Genet. Breed. 2018, 22, 363-369. [CrossRef]

29. Gultyaeva, E.I.; Shaydayuk, E.L.; Shamanin, V.P.; Akhmetova, A.K.; Tyunin, V.A.; Shreyder, E.R.; Kashina, I.V.; Eroshenko, L.A.; Sereda, G.A.; Morgunov, A.I. Genetic structure of Russian and Kazakhstani leaf rust causative agent Puccinia triticina Erikss. populations as assessed by virulence profiles and SSR markers. Agric. Biol. 2018, 5, 85-95. [CrossRef]

30. Gultyaeva, E.I.; Kokhmetova, A.M.; Shreyder, E.R.; Shaydayuk, E.L.; Atishova, M.N.; Madenova, A.; Malysheva, A.; Galymbek, K. Genetic variability of perspective breeding material of spring bread wheat for resistance to leaf rust in Russia and Kazakhstan. Bull. NAS RK 2020, 3, 60-68. [CrossRef]

31. Khan, A.A.; Cheema, H.M.N.; Karim, I.; Aslam, U.; Hussain, M.; Ali, Z. Genetic variance, population structure and gene flow among Triticum aestivum for rust resistance. Pak. J. Agric. Sci. 2017, 54, 819-828. [CrossRef]

32. Kokhmetova, A.; Atishova, M. Identification wheat genotypes resistant to tan spot Pyrenophora tritici-repentis. Bull. NAS RK 2020, 2, 29-35. [CrossRef]

33. Lopez-Vera, E.E.; Nelson, S.; Singh, R.P.; Basnet, B.R.; Haley, S.D.; Bhavani, S.; Huerta-Espino, J.; Xoconostle-Cazares, B.G.; Ruiz-Medrano, R.; Rouse, M.N. Resistance to stem rust Ug99 in six bread wheat cultivars maps to chromosome 6DS. Theor. Appl. Genet. 2014, 127, 231-239. [CrossRef]

34. Randhawa, M.; Bansal, U.; Valárik, M.; Klocová, B.; Doležel, J.; Bariana, H. Molecular mapping of stripe rust resistance gene Yr51 in chromosome 4AL of wheat. Theor. Appl. Genet. 2014, 127, 317-324. [CrossRef] [PubMed]

35. Morgounov, A.; Pozherukova, V.; Kolmer, J.; Gultyaeva, E.; Abugalieva, A.; Chudinov, V.; Kuzmin, O.; Rasheed, A.; Rsymbetov, A.; Shepelev, S.; et al. Genetic basis of spring wheat resistance to leaf rust (Puccinia triticina) in Kazakhstan and Russia. Euphytica 2020, 216, 170. [CrossRef]

36. Kokhmetova, A.M.; Sapakhova, Z.B.; Madenova, A.K.; Esenbekova, G.T. Identification of carriers of genes for resistance to yellow Yr5, Yr10, Yr15 and brown rust Lr26, Lr34 based on molecular screening of wheat samples. Biotech. Theory Pract. 2014, 1, 71-78.

37. Yessenbekova, G.; Kokhmetova, A.; Madenova, A.; Amanov, O.; Dutbayev, Y.; Kampitova, G. Identification of Lr34/Yr18 Gene in Wheat Germplasm in Kazakhstan. In Proceedings of the 2014 APS-CPS Joint Meeting, Minneapolis, MN, USA, 9-13 August $2014 ;$ p. 252.

38. Kokhmetova, A.M.; Atishova, M.N.; Galymbek, K. Identification of wheat germplasm resistant to leaf, stripe and stem rust using molecular markers. Bull. NAS RK 2020, 2, 45-52. [CrossRef]

39. McIntosh, R.A.; Wellings, C.R.; Park, R.F. Wheat Rusts: An Atlas of Resistant Genes; CSIRO: Clayton South, Australia, 1995.

40. Dospekhov, B.A. Methods of Field Experience (With the Basics of Statistical Processing of Research Results), 5th ed.; Kolos: Kovalivka, Ukraine, 1985.

41. Long, D.L.; Kolmer, J.A. North American system of nomenclature for (Puccinia recondita f.sp.) Tritici. Phytopatology 1989, 79, 525-529. [CrossRef]

42. Singh, R.P. Pathogenicity variation of (Puccinia recondita f.sp.) tritici and (P. graminis f.sp.) tritici in wheat-growing areas of Mexico during 1998 and 1989. Plant Dis. 1991, 75, 790-794. [CrossRef]

43. Roelfs, A.P.; Singh, R.P.; Saari, E.E. Rust Diseases of Wheat: Concept and Methods of Disease Management; CIMMYT: México-Veracruz, Mexico, 1992.

44. Mains, E.B.; Jackson, H.S. Physiologic specialization in the leaf rust of wheat; Puccinia triticina Erikss. Phytopatology 1926, 16, 89-120.

45. Oelke, L.M.; Kolmer, J.A. Characterization of leaf rust resistance in hard red spring wheat cultivars. Plant Dis. 2004, 88, 1127-1133. [CrossRef] 
46. Peterson, R.F.; Champbell, A.B.; Hannah, A.E. A diagramatic scale for estimating rust intensity of leaves and stem of cereals. Can. J. Res. 1948, 26, 496-500. [CrossRef]

47. Riede, C.R.; Anderson, J.A. Linkage of RFLP markers to an aluminum tolerance gene in wheat. Crop Sci. 1996, 36, 905-909. [CrossRef]

48. Feuillet, C.; Messmer, M.; Schachermayr, G.; Keller, B. Genetic and physical characterization of the LR1 leaf rust resistance locus in wheat (Triticum aestivum L.). Mol. Gen. Genet. 1995, 248, 553-562. [CrossRef]

49. Schachermayr, G.; Siedler, H.; Gale, M.D.; Winzeler, H.; Winzeler, M.; Keller, B. Identification and localization of molecular markers linked to the Lr9 leaf rust resistance gene of wheat. Theor. Appl. Genet. 1994, 88, 110-115. [CrossRef]

50. Schachermayr, G.; Feuillet, C.; Keller, B. Molecular markers for the detection of the wheat leaf rust resistance gene Lr10 in diverse genetic backgrounds. Mol. Breed. 1997, 3, 65-74. [CrossRef]

51. Zhang, W.; Dubcovsky, J. Association between allelic variation at the Phytoene synthase 1 gene and yellow pigment content in the wheat grain. Theor. Appl. Genet. 2008, 116, 635-645. [CrossRef] [PubMed]

52. Weng, Y.; Azhaguvel, P.; Devkota, R.N.; Rudd, J.C. PCR based markers for detection of different sources of 1AL.1RS and 1BL.1RS wheat-rye translocations in wheat background. Plant Breed. 2007, 126, 482-486. [CrossRef]

53. Vikal, Y.; Chhuneja, P.; Singh, R.; Dhaliwal, H.S. Tagging of an Aegilops speltoides Derived Leaf Rust Resistance Gene Lr28 with a Microsatellite Marker in Wheat. J. Plant Biochem. Biotechnol. 2004, 13, 47-49. [CrossRef]

54. Lagudah, E.S.; McFadden, H.; Singh, R.P.; Huerta-Espino, J.; Bariana, H.S.; Spielmeyer, W. Molecular genetic characterization of the Lr34/Yr18 slow rusting resistance gene region in wheat. Theor. Appl. Genet. 2006, 114, 21-30. [CrossRef] [PubMed]

55. Helguera, M.; Khan, I.A.; Kolmer, J.; Lijavetzky, D.; Zhong-Qi, L.; Dubcovsky, J. PCR Assays for the Cluster of Rust Resistance Genes and Their Use to Develop Isogenic Hard Red Spring Wheat Lines. Crop Sci. 2003, 43, 1839-1847. [CrossRef]

56. Herrera-Foessel, S.A.; Singh, R.P.; Huerta-Espino, J.; Rosewarne, G.M.; Periyannan, S.K.; Viccars, L.; Calvo-Salazar, V.; Lan, C.; Lagudah, E.S. Lr68: A new gene conferring slow rusting resistance to leaf rust in wheat. Theor. Appl. Genet. 2012, 124, 1475-1486. [CrossRef]

57. Chen, X.; Line, R.; Leung, H. Genome scanning for resistance-gene analogs in rice, barley, and wheat by high-resolution electrophoresis. Theor. Appl. Genet. 1998, 97, 345-355. [CrossRef] 